\title{
A Nylon Membrane Bag Assay for Determination of the Effect of Chemicals on Soilborne Plant Pathogens in Soil
}

\author{
Youjian Lin, Indian River Research and Education Center, University of Florida, Fort Pierce 34945 and Plant Pro- \\ tection College, Fujian Agriculture and Forestry University, Fuzhou, Fujian 350002, China; Zhenli He, Indian River \\ Research and Education Center, University of Florida; Erin N. Rosskopf, United States Horticultural Research \\ Laboratory, Fort Pierce, FL 34945; Kenneth L. Conn, Southern Crop Protection and Food Research Centre, Agri- \\ culture and Agri-Food Canada, London, Ontario N5V 4T3, Canada; Charles A. Powell, Indian River Research and \\ Education Center, University of Florida; and George Lazarovits, Southern Crop Protection and Food Research Cen- \\ tre, Agriculture and Agri-Food Canada
}

\begin{abstract}
Lin, Y., He, Z., Rosskopf, E. N., Conn, K. L., Powell, C. A., and Lazarovits, G. 2010. A nylon membrane bag assay for determination of the effect of chemicals on soilborne plant pathogens in soil. Plant Dis. 94:201-206.

A new nylon membrane bag (NMB) assay was developed for studies to determine the effect of chemicals added to soil on survival of soilborne plant pathogens. The rapid and effective assay can be used to study organisms for which there are no selective media or for which a selective medium is expensive or difficult to prepare. This assay consists of placing pathogens inside a bag made of small-pore $(0.22-\mu \mathrm{m})$ nylon filtration membrane, which is placed in soil and later retrieved to determine survival of the pathogens on nonselective media. Chemicals but not other microorganisms can enter the bag from the soil. Using this assay, Streptomyces scabies, Fusarium oxysporum $\mathrm{f}$. sp. lycopersici race 3 , and Ralstonia solanacearum were successfully recovered from soil after $72 \mathrm{~h}$ as demonstrated by growth on a semiselective Streptomyces medium ( $S$. scabies) or nonselective potato dextrose agar medium (F. oxysporum $\mathrm{f}$. sp. lycopersici race 3 and $R$. solanacearum) with minimal microbial contamination. Addition of acetic acid ( $200 \mathrm{mM})$ to soil killed $100 \%$ of S. scabies. SPK (a mixture of organic chemicals) at a concentration of 1,500 $\mathrm{mg} \mathrm{kg}^{-1}$ of soil killed $83.3 \%$ of $F$. oxysporum f. sp. lycopersici race 3 culture plugs, $100 \%$ of $F$. oxysporum f. sp. lycopersici race 3 spores, and $97.2 \%$ of $R$. solanacearum cells. SPK at 1,000 $\mathrm{mg} \mathrm{kg}-1$ of soil killed $50 \%$ of $F$. oxysporum f. sp. lycopersici race 3 culture plugs, $68.2 \%$ of $F$. oxysporum f. sp. lycopersici race 3 spores, and 12\% of $R$. solanacearum. Benlate (500 to 1,500 $\mathrm{mg} \mathrm{kg}{ }^{-1}$ of soil) did not kill the culture plugs of $F$. oxysporum $\mathrm{f}$. sp. lycopersici race 3 but reduced the growth rate of $F$. oxysporum f. sp. lycopersici race 3 . Benlate $(500,1,000$, and 1,500 $\mathrm{mg} \mathrm{kg}^{-1}$ of soil) reduced $F$. oxysporum $\mathrm{f}$. sp. lycopersici race 3 spore germination by 39.4, 49.3, and $50.4 \%$, respectively. Streptomycin sulfate $\left(1,500,800,400\right.$, and $200 \mathrm{mg} \mathrm{kg}^{-1}$ of soil) caused $75.3,21,11.9$, and $0.9 \%$ mortality, respectively, of $R$. solanacearum.
\end{abstract}

Screening chemicals, fungicides, bactericides, soil amendments, and biological control organisms for control of soilborne plant pathogens is one of the most active research areas of plant pathology $(1,28,33,34)$. Methods developed for screening control agents for soilborne pathogens include in vitro and in vivo assays (34). In vitro assays include spore germination $(11,16)$; paper disk diffusion, agar diffusion, and radial growth rate on agar plates $(11,16,17)$; and shake-flask, broth microdilution, and microtiter plate assays $(2,18,22,26,29)$. However, the results obtained by in vitro assays, mostly by agar plate assay procedures $(16,34)$, some-

Corresponding author: C. A. Powell

E-mail: capowell@ufl.edu

Accepted for publication 4 October 2009.

doi:10.1094/PDIS-94-2-0201

(C) 2010 The American Phytopathological Society times correlate poorly with those of largescale in vivo assays in the greenhouse and field $(11,25)$.

In vivo assays take into account soil interactions with control agents and better reflect the eventual effect of control agents on soilborne diseases under field conditions. In vivo assays include soil-pathogen system assays (27,34) and soil-pathogen-plant system assays $(17,27,34)$. Soil-pathogenplant system assays are generally time consuming and laborious whereas soilpathogen system assays are rapid and easier. Therefore, soil-pathogen system assays are more suitable for rapidly screening control agents for soilborne pathogens in laboratories $(5,11,22,34,39,48)$. However, most of the soil-pathogen system assays employ autoclaved or sterile soil instead of using nonsterile or natural soil because of contamination problems that affect the analysis of test results.

Autoclaving destroys or changes the physical, chemical, and biological properties of soil that affect the efficacy of a given control agent. Chemical control materials can undergo various changes in natural soil, including decomposition, which may enhance or reduce control of soilborne pathogens. In addition, control agents can be affected by numerous factors, including but not limited to soil temperature $(6,8)$, aeration (24), microbial populations, $\mathrm{pH}(8,41,43,46)$, organic matter $(21,24)$, clay content $(40)$, cation exchange capacity (24), and moisture $(24,39$, 44,45).

Much effort has been put into developing tools to determine the efficacy of control agents in natural soil $(16,17,26)$. Target organisms can be detected in soil by use of selective media $(14,16,23,42)$, burial and retrieval in nylon net bags (9), or polymerase chain reaction (PCR; 35,47) and immunoassays $(1,2,12,19,20,31,32,38)$. However, there are limits to these assays. For example, PCR detects DNA from soil that may lead to the quantification of dead organisms, and selective media may not be available for target organisms or may be difficult or costly to prepare. Nylon net bag assays with selective media have been successfully used to determine the efficacy of chemicals and soil amendments on soilborne pathogens such as Phytophthora spp., Sclerotium cepivorum, and Verticillium dahlia in natural soil $(4,7,8,42)$. This approach is most useful if selective media are available because microorganisms from soil can enter the bags through the pores. Thus, there is a need to develop assays that can rapidly and effectively determine the effect of chemicals added to soil on soilborne pathogens for which there are no selective media available.

In this article, we describe a nylon membrane bag (NMB) assay procedure which is different from nylon net bag assays in that small-pore $(0.22-\mu \mathrm{m})$ nylon filtration membranes were used instead of large-pore (5- to 20- $\mu \mathrm{m}$ ) nylon net. Using this NMB assay, various combinations of four chemicals (acetic acid, benomyl, streptomycin sulfate, and SPK [a proprietary mixture of organic chemicals]), two soils, and three soilborne pathogens (Streptomyces scabies, Ralstonia solanacearum, and Fusarium oxysporum f. sp. lycoper- 
sici) were tested. Assessment of pathogen survival from the NMB assay was performed using nonselective or semiselective media.

\section{MATERIALS AND METHODS}

Soils. Soil was collected at 0 to $15 \mathrm{~cm}$ of depth from a commercial potato field in Ontario, Canada (site G) and from a vegetable field in St. Lucie County, FL (site F). Site $\mathrm{G}$ soil was a sandy loam, Luvisolic, with a $\mathrm{pH}$ of 7.1 and organic carbon content of $12 \mathrm{~kg}^{-1}$ of soil. Site $\mathrm{F}$ soil was sandy, siliceous, hyperthermic, Arenic, Glossaqualf with a $\mathrm{pH}$ of 7.6 and organic carbon content of $9.06 \mathrm{~g} \mathrm{~kg}^{-1}$ of soil. Soils were air dried, passed through a 2-mm sieve, and stored at room temperature $\left(24^{\circ} \mathrm{C}\right)$ prior to use. The water content of the soils was gravimetrically adjusted to $10 \%$ by adding deionized water before use. Then, the soils were weighed and treated with chemicals in the tests.

Preparation of $S$. scabies inoculum. An isolate of the soilborne plantpathogenic bacterium, S. scabies strain SP, isolated from soil in Ontario, Canada (9) was used in this study. Spores from 2week-old cultures grown on yeast malt extract (YME) agar medium were scraped off of the plate into sterile deionized water. The spore suspension was passed through a glass-wool filter to remove any excess growth media and finally suspended in 30 $\mathrm{ml}$ of sterile deionized water to get a uniform concentration prior to use. The con- centration of spores was estimated by measuring absorbance at $590 \mathrm{~nm}$. Viability of spores after exposure to chemicals in $\mathrm{G}$ site soil was determined by culturing on semiselective Streptomyces medium (STR medium) $(3,9)$.

Preparation of $\boldsymbol{F}$. oxysporum f. sp. $l y$ copersici inoculum. An isolate (no. 9602) of the soilborne plant-pathogenic fungus $F$. oxysporum f. sp. lycopersici race 3 (3), obtained from an infected tomato plant in a commercial production field in Saint Lucie County, FL, was used in this study. The culture of $F$. oxysporum f. sp. lycopersici race 3 was recovered from sterile soil tubes and grown on potato dextrose agar (PDA) medium (Difco Becton, Dickinson and Co., Sparks, MD) for 10 to 15 days. Agar plugs, consisting of a mixture of mycelia and spores of $F$. oxysporum f. sp. lycopersici race 3 , were cut out of the cultures with a cork borer $(1.0 \mathrm{~cm}$ in diameter). The culture plugs were completely dried by airflow in a Safeair class II safety cabinet for 12 to $24 \mathrm{~h}$ before use. The spore suspension, prepared by adding $15 \mathrm{ml}$ of sterile deionized water to a culture plate and scraping off spores, was ready for use. The resulting spore suspension contained a mixture of micro- and macroconidia. The spore suspension was passed through a glass-wool filter to remove any excess growth medium and large pieces of mycelium. Uniform concentrations of spore suspension were used for all the treatments in each experiment. Viability of spores and mycelia after exposure to chemicals in $\mathrm{F}$ site soil was determined by culturing on PDA and treatments were compared with an untreated control (4).

Preparation of $R$. solanacearum inoculum. An isolate of the soilborne plantpathogenic bacterium, $R$. solanacearum (race 1, biovar 1; tomato strain Rs5), isolated in Quincy, FL $(36,37)$ was used in this study. $R$. solanacearum was grown at $28^{\circ} \mathrm{C}$ either on casamino acid peptone glucose (CPG) agar medium (10 $\mathrm{g}$ of peptone, $1 \mathrm{~g}$ of casamin acids, $2.5 \mathrm{~g}$ of dextrose, $15 \mathrm{~g}$ of agar, and 1 liter of deionized water) for 48 hours or in CPG broth on a shaker (200 rpm) for $18 \mathrm{~h}$ (overnight; 36). Bacterial cells from 18-h CPG-broth culture were diluted with sterile deionized water prior to use. The concentration of the cells in the suspension was estimated by measuring absorbance at $590 \mathrm{~nm}$. Viability of $R$. solanacearum after exposure to chemicals in F site soil was determined by culturing on PDA.

Chemicals. Chemicals added to the soils included glacial acetic acid $(99.8 \%$, Fisher Scientific), a broad-spectrum antimicrobial chemical that can kill soilborne plant pathogens $(10,43)$; benomyl (Benlate $50 \%$ WP; DuPont, Wilmington, DE), a broad-spectrum systemic fungicide (13); streptomycin sulfate (Sigma-Aldrich, St. Louis), an aminoglycoside antibiotic for controlling bacterial diseases of crops (30); and SPK, a formulation of organic chemicals recently developed in our laboratory

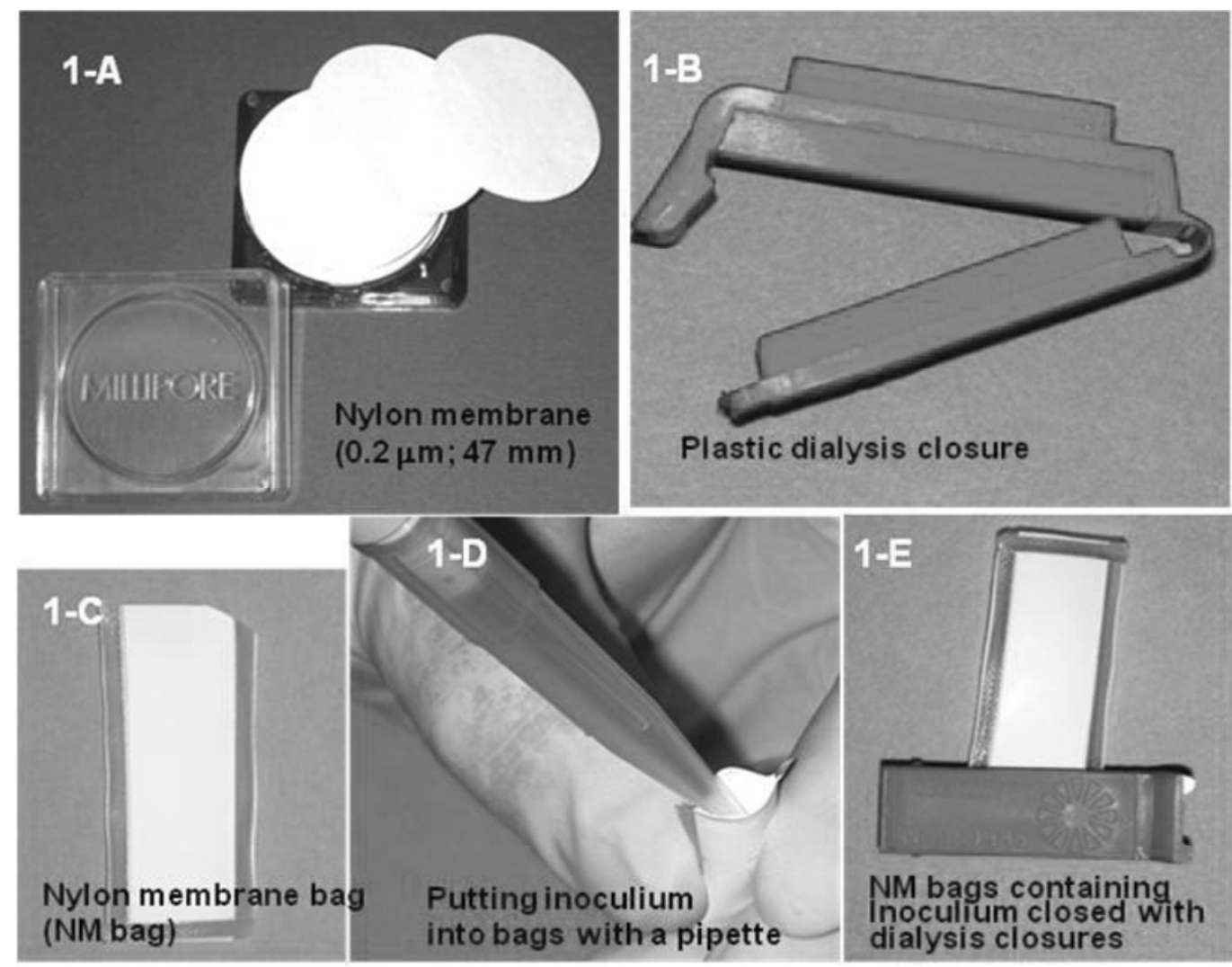

Fig. 1. Illustration of materials and main steps for using a nylon membrane bag (NMB) assay. A, Nylon membrane; B, dialysis closure; C, prepared NMBs; $\mathbf{D}$, placement of spore suspension into NMBs; and $\mathbf{E}$, closure of NMBs with a dialysis closer. 
for controlling soilborne plant pathogens (Indian River Research and Education Center, University of Florida and United States Horticultural Research Laboratory, United States Department of AgricultureAgricultural Research Service, patent pending; details of the composition can be made available to other investigators upon signing nondisclosure letter). The NMB assay was used to test toxicity of acetic acid against $S$. scabies, benomyl against $F$. oxysporum f. sp. lycopersici race 3, streptomycin against $R$. solanacearum, and SPK against both $F$. oxysporum f. sp. lycopersici race 3 and $R$. solanacearum. The concentration of acetic acid used was 200 $\mathrm{mM}$ in the water component of the soil. To achieve this, $0.5 \mathrm{ml}$ of acetic acid $(4.2 \mathrm{M})$ was added to $99.5 \mathrm{~g}$ of soil, giving a final moisture content of $10 \%$. The concentrations used were benomyl at 500, 1,000, and $1,500 \mathrm{mg} \mathrm{kg}^{-1}$ of soil; streptomycin sulfate at $200,400,800$, and $1,500 \mathrm{mg} \mathrm{kg}^{-1}$ of soil; and SPK at 500, 1,000, and 1,500 mg kg-1
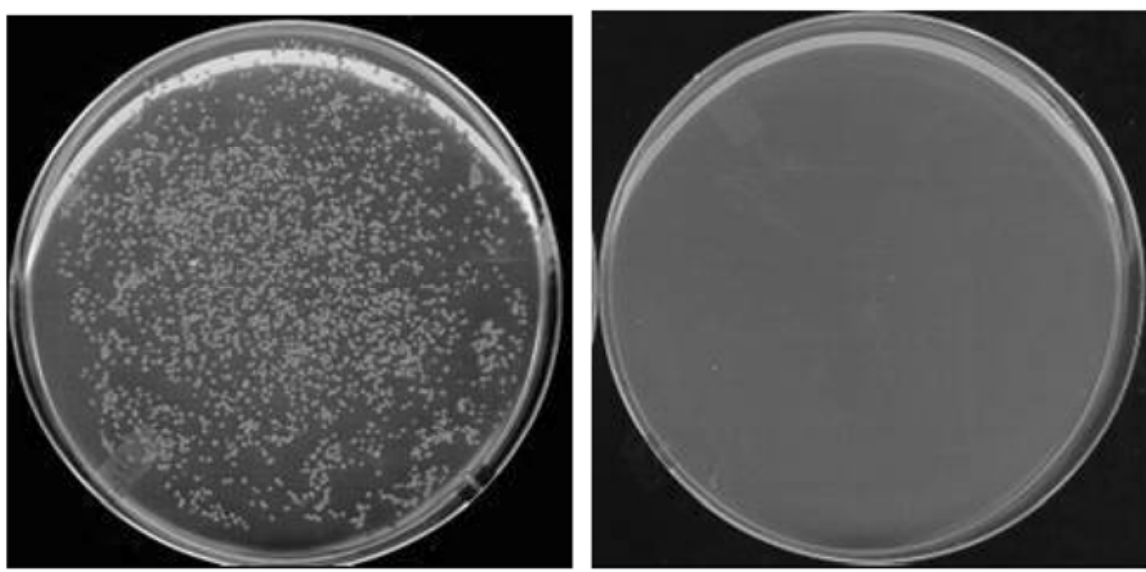

Fig. 2. Colonies of Streptomyces scabies growing on Streptomyces medium after a 72-h exposure in a nylon membrane bag to untreated natural soil (left) or soil amended with acetic acid (200 $\mathrm{mM}$ in water component of soil, right). The soil was a sandy-loam soil from a commercial potato field in Ontario, Canada.

of soil. Each trial contained an untreated check with no chemical treatment for comparison of viability or mortality.

Construction of NMBs. NMBs ( 8 by $30 \mathrm{~mm}$ ) were made of Millipore nylon hydrophilic membrane filter discs $(0.22-$ $\mu \mathrm{m}$ pore size and $47 \mathrm{~mm}$ in diameter, Millipore Corporation, Billerica, MA) and dialysis closures (23-mm width; Spectrum Laboratories, Inc.; Fig. 1A and B). An electron bag sealer (Daigger Lab Supplies, Vernon Hills, IL) was used to seal a section of the folded nylon-membrane disk in a rectangular shape for a final size of 4 by 0.8 $\mathrm{cm}$. One of the two short-side edges was left unsealed (open) for placement of the pathogen suspensions or plugs (Fig. 1C).

NMB assay procedure. Effect of the various chemicals on S. scabies, F. oxysporum f. sp. lycopersici race 3 , or $R$. solanacearum was determined by the NMB assay. Cell suspensions $(200 \mu \mathrm{l})$ of $S$. scabies or $R$. solanacearum or air-dried culture plugs (consisting of mycelia and
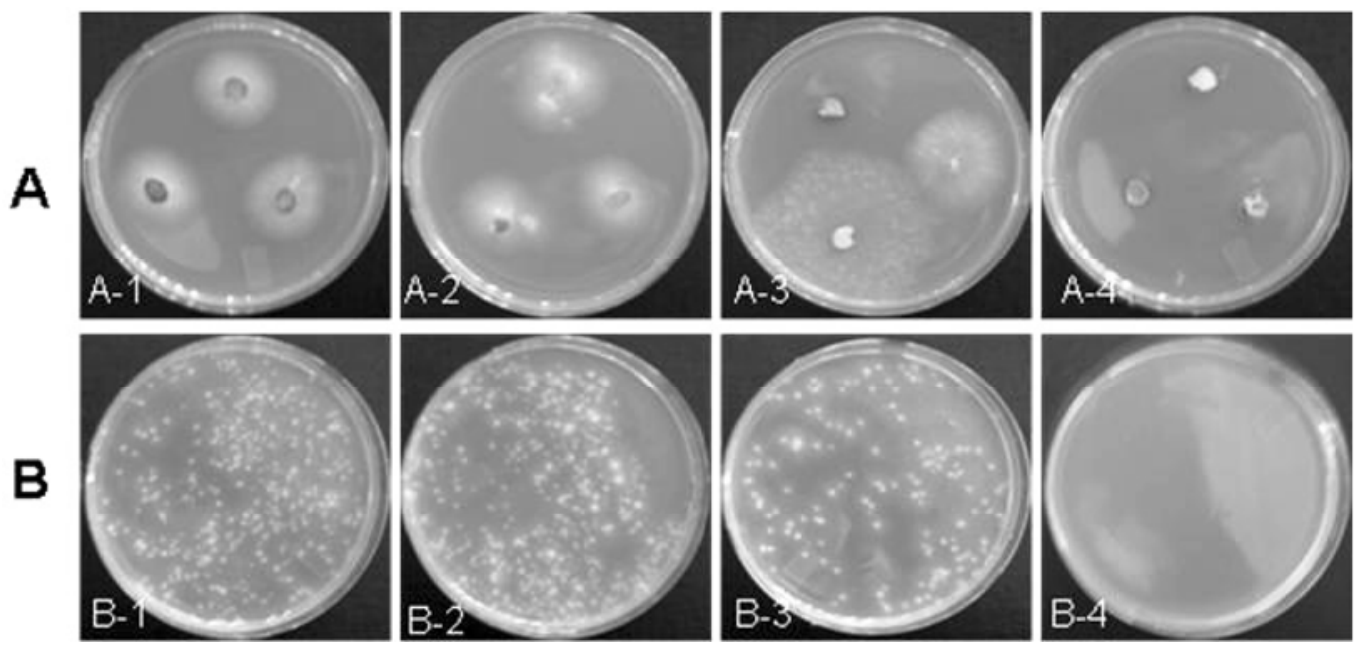

Fig. 3. Growth from culture plugs and micro- and macroconidia of Fusarium oxysporum f. sp. lycopersici race 3 on potato dextrose agar after a 72-h exposure in a nylon membrane bag to natural soil amended with SPK (a novel mixture of organic chemicals). A, Growth of $F$. oxysporum f. sp. lycopersici race 3 from culture plugs in $\mathbf{1}$, untreated control or SPK at $\mathbf{2}, 500 ; \mathbf{3}, 1,000 ;$ or $\mathbf{4}, 1,500 \mathrm{mg} \mathrm{kg}^{-1}$ of soil. B, Growth of F. oxysporum f. sp. lycopersici race 3 from of spores in the treatments $\mathbf{1}$, untreated control or SPK at $\mathbf{2}, 500 ; \mathbf{3}, 1,000$; or $\mathbf{4}, 1,500 \mathrm{mg} \mathrm{kg}^{-1}$ of soil. 


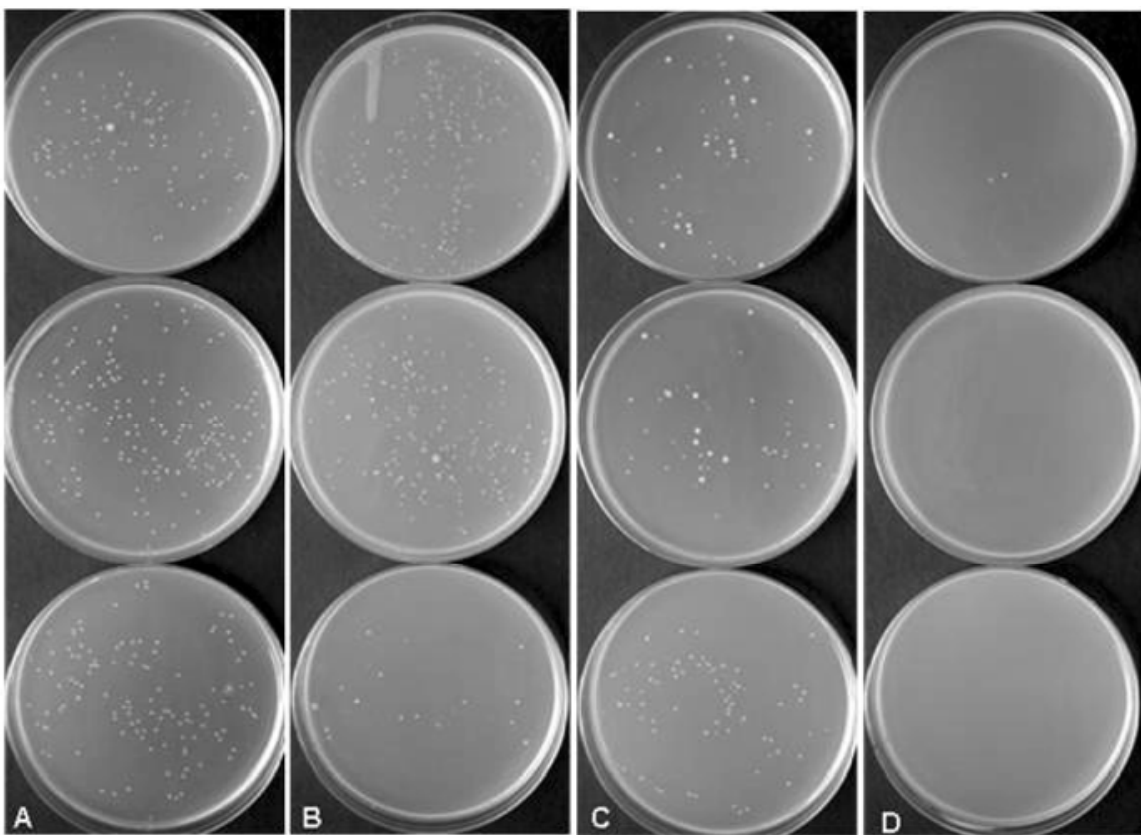

Fig. 4. Colonies of Ralstonia solanacearum (race 1, biovar 1; tomato strain Rs5) growing on potato dextrose agar after a 72-h exposure to soil amended with SPK (mixture of organic chemicals) using a nylon membrane bag assay. Soil was a sandy, siliceous, hyperthermic, Arenic, Glossaqualf from a vegetable field in Florida. A, Untreated control or SPK at B, 500; C, 1,000; or D, 1,500 mg kg-1 of soil.

The plates were incubated at room temperature and examined after 3 and 7 days to determine the survival of the microbial propagules. The effectiveness of the chemicals on the pathogens was determined based on the viability of the pathogens. The experiments were conducted twice for the chemicals, pathogens, and soils. For S. scabies, three NMBs were placed into each of three vessels per treatment for each experiment. For $F$. oxysporum f. sp. lycopersici race 3 and $R$. solanacearum, there were three NMBs for each treatment in each experiment. The treatments, treated and untreated soil, and pathogen propagules in the experiment were randomized completely in the use of materials such as vessels and pathogen propagules prepared in nylon bags and the placement of vessel arrangement in incubation. The significant difference of the data was analyzed by a $t$ test. Also, statistical regression analysis of data was conducted using SigmaPlot 10.0 (SPSS Inc., Richmond, CA).

\section{RESULTS}

Very little microbial contamination resulted from the NMB assay for the pathogens tested (Figs. 2, 3, and 4). Even on a nonselective medium such as PDA, few nontarget organisms were observed (Fig. 3).

Effect of acetic acid on $S$. scabies in soil. A 72-h exposure of $S$. scabies to acetic acid in soil resulted in almost $100 \%$ mortality (Table 1; Fig. 2). Very little microbial contamination was observed on the agar medium (Fig. 2) (8). S. scabies colonies grew from the control treatment and almost nothing grew from the acetic acid treatment.

Effect of SPK on $F$. oxysporum f. sp. lycopersici and $R$. solanacearum in soil. After a $72 \mathrm{~h}$ of incubation, SPK at the concentration of $1,500 \mathrm{mg} \mathrm{kg} \mathrm{k}^{-1}$ of soil killed $83.3 \%$ of $F$. oxysporum f. sp. lycopersici race 3 culture plugs (Table 2), $100 \%$ of $F$. oxysporum f. sp. lycopersici race 3 spores (Table 2), and $97.2 \%$ of $R$. solanacearum cells (Table 3 ) in the NMBs placed in soil. SPK at $1,000 \mathrm{mg} \mathrm{kg}^{-1}$ of soil killed $50 \%$ of $F$. oxysporum f. sp. lycopersici race 3 culture plugs (Table 2), $68.2 \%$ of $F$. oxysporum f. sp. lycopersici race 3 spores (Table 2), and $12 \%$ of $R$. solanacearum (Table 3). SPK at $500 \mathrm{mg}$ $\mathrm{kg}^{-1}$ did not kill $F$. oxysporum f. sp. lycopersici race 3 culture plugs or spores (Table 2) or R. solanacearum (Table 3 ). The effects of SPK concentrations on survival of $F$. oxysporum f. sp. lycopersici race 3 and $R$. solanacearum in soil were significant. The regression equation of $F$. oxysporum f. sp. lycopersici race 3 spore mortality $(y)$ and the SPK concentration $(x)$ was $y=3 \mathrm{E}-05 x^{2}+0.0282 x-4.975\left(R^{2}=\right.$ $0.9334 ; P<0.01)$, and the regression equation of $R$. solanacearum mortality $(y)$ and the SPK concentration $(x)$ was $\mathrm{y}=8 \mathrm{E}-$ $0.01)$.

Effect of benlate on $F$. oxysporum $f$. sp. lycopersici in soil. After $72 \mathrm{~h}$ of incubation, benlate at the concentrations of 500 to $1,500 \mathrm{mg} \mathrm{kg}^{-1}$ of soil reduced growth from but did not kill the culture plugs of $F$. oxysporum f. sp. lycopersici race 3 (Table $2)$. The average colony diameter of $F$. $o x$ ysporum f. sp. lycopersici race 3 in un$05 x^{2}-0.066 x+3.1875\left(R^{2}=0.969 ; P \leq\right.$
Table 1. Survival of Streptomyces scabies in a nylon membrane bag (NMB) after burial in soil treated with acetic acid ${ }^{a}$

\begin{tabular}{lcc}
\hline Treatments & No. of colonies & $\begin{array}{c}\text { Mortality } \\
(\boldsymbol{\%})\end{array}$ \\
\hline Trial I & & \\
Untreated & $11,000 \pm 1,400$ & $\ldots$ \\
Acetic acid & $27 \pm 17$ & 99.8 \\
Trial II & & \\
Untreated & $33,000 \pm 3,000$ & $\ldots$ \\
Acetic acid & $0.0 \pm 0.0$ & 100 \\
\hline
\end{tabular}

a NMBs containing S. scabies were placed into vessels containing untreated soil or soil treated with acetic acid $(200 \mathrm{mM}$ in water component of soil). Soil was a sandy-loam soil from a commercial potato field in Ontario, Canada. Bags were removed after $72 \mathrm{~h}$ and plated onto Streptomyces medium. Number of colonies are means \pm standard error $(n=9)$.

treated controls was $3.3 \pm 0.4 \mathrm{~cm}$, while those treated with 500,1,000, and 1,500 $\mathrm{mg} \mathrm{kg}-1$ of soil were $2.3 \pm 0.6,2.3 \pm 0.4$, and $2.2 \pm 0.4 \mathrm{~cm}$, respectively $(n=6)$. Benlate killed spores of $F$. oxysporum $\mathrm{f}$. sp. lycopersici race 3 in soil (Table 2). The mortality of spores was $50.4 \%$ at $1,500 \mathrm{mg}$ $\mathrm{kg}^{-1}$ of soil. Statistical analysis indicated that mycelium diameter and conidial survival differed between the control and benlate treatments ( $t$ test, $P=0.05$ ) but not among the different benlate concentrations. The regression equation of the $F$. oxysporum f. sp. lycopersici race 3 spore mortality $(y)$ and the benlate concentration $(x)$ was $y=-4 \mathrm{E}-05 x^{2}+0.0897 x+1.035$ $\left(R^{2}=0.9873\right)$.

Effect of streptomycin on $R$. solanacearum in soil. The toxicity of streptomycin on $R$. solanacearum increased with its concentration in soil after a 72-h exposure (Table 3). The highest mortality, $75.3 \%$, of $R$. solanacearum occurred in the soil treated with streptomycin at $1,500 \mathrm{mg} \mathrm{kg}^{-1}$ of soil. The mortality of $R$. solanacearum among the control and treatments of streptomycin at concentrations ranging from 400 to $1,500 \mathrm{mg} \mathrm{kg}^{-1}$ of soil was significantly different ( $t$ test, $P=0.01$ ) but not between the control and the treatment of streptomycin at the $200 \mathrm{mg} \mathrm{kg}$-1 of soil concentration $(P=0.05)$. The regression equation of the $R$. solanacearum mortality $(y)$ and the streptomycin concentration $(x)$ in soil was $y=3 \mathrm{E}-05 x^{2}+0.0068 x+0.318$ $\left(R^{2}=0.9927\right)$.

\section{DISCUSSION}

The new NMB assay can be used to rapidly and effectively determine the effect of chemicals added to soil on survival of soilborne plant pathogens. This assay consists of placing pathogens inside a bag made of small-pore $(0.22-\mu \mathrm{m})$ nylon filtrate membrane which is placed in soil and later retrieved to determine survival of the pathogens on nonselective or semiselective media. A novel component of this assay is that chemicals but not microorganisms can enter the bag from the soil. S. scabies, $F$. 
Table 2. Mortality of Fusarium oxysporum f. sp. lycopersici micro- and macroconidia pores and mycelia in nylon membrane bags (NMBs) after burial in soil treated with benlate and SPK (a novel mixture of organic chemicals) ${ }^{\mathrm{a}}$

\begin{tabular}{lccc}
\hline $\begin{array}{l}\text { Treatments } \\
\left(\mathbf{m g ~ k g}^{-1} \text { of soil) }\right.\end{array}$ & $\begin{array}{c}\text { No. of viable mycelium } \\
\text { plugs/no. of plugs tested }\end{array}$ & $\begin{array}{c}\text { No. of colonies } \\
\text { from spores }\end{array}$ & $\begin{array}{c}\text { Spore mortality } \\
(\%)\end{array}$ \\
\hline Untreated & $6 / 6$ & $245,000 \pm 45,000$ & 0.0 \\
Benlate & & & \\
500 & $6 / 6$ & $148,500 \pm 15,000$ & 39.4 \\
1,000 & $5 / 6$ & $124,000 \pm 7,000$ & 49.3 \\
1,500 & $6 / 6$ & $12,1500 \pm 3,500$ & 50.4 \\
SPK & & & \\
500 & $6 / 6$ & $240,800 \pm 28,900$ & 1.7 \\
1,000 & $3 / 6$ & $177,900 \pm 11,500$ & 68.2 \\
1,500 & $1 / 6$ & 0 & 100.0 \\
\hline
\end{tabular}

${ }^{a}$ NMBs containing of $F$. oxysporum f. sp. lycopersici were placed into vessels containing untreated soil or soil treated with benlate or SPK. Soil was a sandy, siliceous, hyperthermic, Arenic, Glossaqualf soil from a vegetable field in Florida. Bags were removed after $72 \mathrm{~h}$ and plated onto potato dextrose agar. Number of colonies are means \pm standard error from two experiments $(n=6)$.

oxysporum f. sp. lycopersici race 3 , and $R$. solanacearum were successfully recovered from soil after $72 \mathrm{~h}$, as demonstrated by growth on a semiselective STR medium $(S$. scabies) or nonselective PDA medium with minimal microbial contamination. This assay was especially useful for testing the effect of chemicals on fungal mycelia in soil because the fungal mycelia (culture plugs) could be easily transferred onto nonselective media, such as the PDA used in this test, to determine viability.

In this study, only nonselective PDA medium or semiselective STR media were used to determine the viability of pathogens after they were exposed to chemicals in soil. However, we believe that, if the NMB assay is combined with selective media, it may become an even more powerful and useful assay for testing the effect of control agents on different kinds of soilborne pathogens. This assay provides a tool that can be used in native, unpasteurized soils; thus, the test results may more closely reflect the efficacy of the control agents in the field. However, there are some factors that may affect the assay results. The NMBs must be checked for leakage after organisms are added and the bags are sealed. Leaking may cause contamination and affect test results. The second is the rinsing of NMBs. We found that rinsing the NMBs with running tap water and with sterile deionized water and brushing the surface of the bags with a soft brush during the rinse, then immediately placing the clean NMBs into sterile containers until they are opened under a safety cabinet, can reduce the risk of contamination.

Some of the results obtained by the NMB assay were different from previous reports. For example, benlate at concentrations ranging from 500 to $1,500 \mathrm{mg} \mathrm{kg}^{-1}$ of soil did not kill $F$. oxysporum f. sp. $l y$ copersici race 3 , and streptomycin at concentrations ranging from 200 to $1,500 \mathrm{mg}$ $\mathrm{kg}^{-1}$ of soil did not completely kill $R$. solanacearum. Previous work using agar plate assays or field tests suggested that benlate is effective for control of Fusarium spp. (15) and streptomycin is deleterious to Ralstonia spp. (30). The results obtained by in vitro assays in previous reports may not show the direct or indirect effects of the chemicals on the pathogens when applied to natural soil. The NMB assay may include direct effects of the test chemical and effects mediated by factors present in natural soil. The lack of effect may also be strain specific, because the baseline sensitivity of these isolates to the test materials was not characterized. Second, the results in our tests were obtained after a 72-h interaction between the control agents and pathogens in soil, whereas previous field tests were conducted over several months. Additionally, the membrane may affect the exposure of the pathogens to the chemicals in soil due to the small size of pores. The suitability of the NMB assay for testing effects of longer interactions between the chemicals and pathogens in soil is unknown.

Prior to this study, toxicity of acetic acid added to soil to had not been demonstrated for S. scabies. A previous study demonstrated with a nylon net bag assay that acetic acid kills $V$. dahliae in soil (10). The results of the NMB assay confirmed that acetic acid can kill S. scabies in soil and may partially explain the fact that liquid swine manure, which contains acetic acid, can reduce potato scab caused by $S$. $s c a-$ bies (7)

Although this NMB assay allows the study of interactions between chemicals in soil and pathogens, it cannot take into account potential interactions between the chemicals, microorganisms in soil but outside the bags, and pathogens in the bags. Sublethal doses of chemicals may not kill the pathogens but may stimulate or suppress the growth of other organisms which, in turn, could affect pathogen growth, survival, or ability to cause disease.

In summary, the NMB assay is a rapid, reliable, and effective assay for evaluating the effect of chemicals on soilborne pathogens in natural soil. The NMB assay can be used to investigate the interactions be-
Table 3. Mortality of Ralstonia solanacearum (race 1, biovar 1; tomato strain Rs5) in nylon membrane bags (NMBs) after burial in soil treated with streptomycin sulfate and SPK (a novel mixture of organic chemicals) ${ }^{\mathrm{a}}$

\begin{tabular}{lcc}
\hline $\begin{array}{l}\text { Treatments } \\
\left(\mathbf{m g ~ ~ k g ^ { - 1 }} \text { of }\right. \\
\text { soil) }\end{array}$ & No. of colonies & $\begin{array}{c}\text { Mortality } \\
(\%)\end{array}$ \\
\hline Untreated & $258,000 \pm 32600$ & $\ldots$ \\
Streptomycin & & \\
200 & $256,000 \pm 16,500$ & 0.9 \\
400 & $227,000 \pm 78,100$ & 11.9 \\
800 & $204,000 \pm 82,900$ & 21.6 \\
1,500 & $63,800 \pm 42,300$ & 75.3 \\
SPK & & \\
500 & $236,200 \pm 11,800$ & 0.85 \\
1,000 & $227,300 \pm 12,800$ & 12.0 \\
1,500 & $7,200 \pm 5,200$ & 97.2 \\
\hline
\end{tabular}

${ }^{a}$ NMBs containing $R$. solanacearum (Race 1 , biovar 1; tomato strain Rs5) were placed into vessels containing untreated soil or soil treated with streptomycin sulfate or SPK. Soil was a sandy, siliceous, hyperthermic, Arenic, and Glossaqualf soil from a vegetable field in Florida. Bags were removed after $72 \mathrm{~h}$ and plated onto potato dextrose agar. Number of colonies are means \pm standard error from two experiments $(n=6)$.

tween soil properties and the efficacy of chemicals in the control of soilborne pathogens in soil. For example, the effect of moisture, temperature, $\mathrm{pH}$, and concentrations of related specific elements on the efficacy of chemicals on soilborne pathogens can be examined using this assay. In addition, this assay can be used to determine the duration of chemical activity in soil in the laboratory.

\section{ACKNOWLEDGMENTS}

We thank T. M. Momol and P. Ji for providing the isolate of $R$. solanacearum (race 1, biovar 1 ; tomato strain Rs5) and M. A. Ritenour and C. Ohs for their critical comments with regard to the preparation of the manuscript.

\section{LITERATURE CITED}

1. Boam, M., and Boland, G. J. 2000. Evaluation of polyclonal-antibody-based immunoassays for detection of Sclerotinia sclerotiorum on canola petals, and prediction of stem rot. Can. J. Microbiol. 46:723-729.

2. Cahill, D. M., and Hardham, A. R. 1994. A dipstick immunoassay for the specific detection of Phytophthora cinnamomi in soil. Phytopathology 84:1284-1292.

3. Chellemi, D. O., Dankers, H. A., and Crosier, B. 1992. First Report of Fusarium oxysporum f. sp. lycopersici race 3 on tomato in Northwest Florida and Georgia. Plant Dis. 76:861.

4. Chellemi, D. O., Olson, S. M., and Mitchell, D. J. 1994. Effect of soil solarization and fumigation on survival of soilborne pathogens of tomato in northern Florida. Plant Dis. 78:11671172.

5. Chinn, S. H. F., and Ledingham, R. J. 1962. A laboratory method for testing the fungicidal effect of chemicals on fungal spores in soil. Phytopathology 52:1041-1044.

6. Coley-Smith, J. R. 1990. White rot disease of Allium: problems of soil-borne diseases in microcosm. Plant Pathol. 39:214-222.

7. Conn, K. L., and Lazarovits, G. 1999. Impact of animal manures on Verticillium wilt, potato scab, and soil microbial populations. Can. J. Plant Pathol. 21:81-92. 
8. Conn, K. L., and Lazarovits, G. 2000. Soil factors influencing the efficacy of liquid swine manure added to soil to kill Verticillium dahliae. Can. J. Plant Pathol. 22:400-406.

9. Conn, K. L., Leci, E., Kritzman, G., and Lazarovits, G. 1998. A quantitative method for determining soil populations of Streptomyces and differentiating potential potato scabinducing strains. Plant Dis. 82:631-638.

10. Conn, K. L., Tenuta, M., and Lazarovits, G. 2005. Liquid swine manure can kill Verticillium dahliae microsclerotia in soil by volatile fatty acid, nitrous acid, and ammonia toxicity. Phytopathology 95:28-35.

11. Corden, M. E., and Young, R. A. 1961. Evaluation of eradicant soil fungicides in the laboratory. Phytopathology 52:503-509.

12. De Cal, A., Martinez-Treceno, A., Salto, T., Lopez-Aranda, J. M., and Melgarejo, P. 2005. Effect of chemical fumigation on soil fungal communities in Spanish strawberry nurseries. Appl. Soil Ecol. 28:47-56.

13. Edgington, L. V., Khew, K. L., and Barron, G. L. 1971. Fungi toxic spectrum of benzimidazole compounds. Phytopathology 61:42-48.

14. Engelbrecht, M. C. 1994. Modification of a semi-selective medium for the isolation and quantification of Pseudomonas solanacearum. ACIAR Proc. 10:3-5.

15. Evens, S. G. 1976. Evaluation of benomyl soil drenches for the control of Verticillium and Fusarium wilt of Carnations. Plant Pathol. 25:81-84.

16. Fang, Z. D. 1979. Methods for Research on Plant Diseases. Agriculture Press, Beijing.

17. Forster, H., Kanetis, L., and Adaskaveg, J. E. 2003. Spiral gradient dilution, a rapid method for determining growth response and $50 \%$ effective concentration values in fungusfungicide interactions. Phytopathology 94:163170.

18. Gadd, G. M. 1986. Toxicity screening using fungi and yeast. Pages 43-77 in: Toxicity Testing Using Microorganisms, Vol. II. B. J. Dutka and G, Bitton, eds. CRC Press, Boca Raton, FL.

19. Gan, Z., Marquardt, R. R., Abramson, D., and Clear, R. M. 1997. The characterization of chicken antibodies raised against Fusarium spp. by enzyme-linked immunosorbent assay and immunoblotting. Int. J. Food Microbiol. 38:191-200.

20. Gautam, Y., Cahill, D M., and Hardham, A. R. 1999. Development of a quantitative immunodipstick assay for Phytophthora nicotianae. Food Agric. Immunol. 11:229-242.

21. Gottlieb, D., Siminoff, P., and Martin, M. M. 1952. The production and role of antibiotics in soil. IV. Actidione and clavacin. Phytopathology 42:493-496.
22. Hadacek, F., and Gregr, H. 2000. Testing of antifungal natural products: methodologies, comparability of results and assay choice. Phytochem. Anal. 11:137-147.

23. Hawke, M. A., and Lazarovits, G. 1994. Production and manipulation of individual microsclerotia of Verticillium dahliae for use in studies of survival. Phytopathology 84:883-890.

24. Kaufman, D. D. 1977. Soil-fungicide interactions. Pages 1-49 in: Antifungal Compounds. Vol. II Interactions in Biological and Ecological Systems. M. R. Siegel and H. D. Sisler, eds. Marcel Dekker, Inc., New York.

25. Knight, S. C. A., Anthony, V. M., Brady, A. M., Greenland, A. J., Heaney, S. P., Murray, D. C., Powell, K. A., Schulz, M. A., Spinks, C. A., Worthington, P. A., and Youle, D. 1997. Rationale and perspectives on the development of fungicides. Annu. Rev. Phytopathol. 35:349372.

26. Kuhajek, J. M., Jeffers, S. N., Slattery, M., and Wedge, D. E. 2003. A rapid microbioassay for discovery of novel fungicides for Phytophthora spp. Phytopathology 94:46-53.

27. Latham, A. J., and Linn, M. B. 1968. A comparison of soil column and petri dish techniques for the evaluation of soil fungitoxicants. Phytopathology 58:460-463.

28. Lazarovits, G., Tenuta, M., and Conn, K. L. 2001. Organic amendments as a disease control strategy for soilborne diseases of highvalue agricultural crops. Australas. Plant Pathol. 30:111-117.

29. Major, J. S. 1995. Current screening practices in the pharmaceutical industry. Proc. Briton Crop. Weeds 1:89-96.

30. McManus, P. S., Stockwell, V. O., Sundin, G. W., and Jones, A. L. 2002. Antibiotic used in plant agriculture. Annu. Rev. Phytopathol. 40:443-465.

31. Miller, S. A., Bhat, R. G., and Schmitthenner, B. 1994. Detection of Phytophthora capsici in pepper and cucurbit crops in Ohio with two commercial immunoassay kits. Plant Dis. 78:1042-1046.

32. Miller, S. A., Madden, L. V., and Schmitthenner, B. 1997. Distribution of Phytophthora spp. in field soils determined by immunoassay. Phytopathology 87:101-107.

33. Noling, J. W. 2002. The practical realities of alternatives to methyl bromide: concluding remarks. Phytopathology 92:1373-1375.

34. Pelletier, E. N. 1977. Detecting potential protective and systemic antifungal compounds. Pages 51-68 in: Antifungal Compound. Vol. I. Discovery, Development, and Uses. M. R. Siegel and H. D. Sisler, eds. Marcel Dekker, Inc., New York

35. Poussier, S., Cheron, J., Couteau, A., and Luisetti, J. 2002. Evaluation of procedures for reliable PCR detection of Ralstonia solanacearum in common natural substrates. J. Microbiol. Methods 51:349-359.

36. Pradhanang, P. M., Ji, P., Momol, M. T., Olson, S. M., Mayfield, J. L., and Jones, J. B. 2005 Application of acibenzolar-s-methyl enhances host resistance in tomato. Plant Dis. 89:989 993.

37. Pradhanang, P. M., and Momol, M. T. 2001 Survival of Ralstonia solanacearum in soil under irrigated rice culture and aquatic weeds. J. Phytopathol. 149:707-711.

38. Robold, A. V., and Hardham, A. R. 1998 Production of species-specific monoclonal antibodies that react with surface components on zoospores and cysts of Phytophthora nicotianae. Can. J. Microbiol. 44:1161-1170.

39. Saeed, I. A. M., Rouse, D. I., Harkin, J. M., and Smith, K. P. 1997. Effects of soil wate content and soil temperature on efficacy of metham-sodium against Verticillium dahliae. Plant Dis. 81:773-776.

40. Sanchez-Martin, M., Andrades, M. S., and Sanchez-Camazano, M. 2000. Soil properties influencing the adsorption and mobility of penconazole in vineyard soils. Soil Sci. 165:951-960.

41. Sheng, G., Yang, Y., Huang, M., and Yang, K 2005. Influence of $\mathrm{pH}$ on pesticide sorption by soil containing wheat residue-derived char Environ. Pollut. 134:457-463.

42. Smolinska, U. 2000. Survival of Sclerotium cepivorum sclerotia and Fusarium ox ysporum chlamydospores in soil amended with cruciferous residues. J. Phytopathol. 148:343-349

43. Tenuta, M., Conn, K. L., and Lazarovits, G. 2002. Volatile fatty acids in liquid swine manure can kill microsclerotia of Verticillium dahliae. Phytopathology 92:548-552.

44. Thiele-Bruhn, S. 2003. Pharmaceutical antibiotic compounds in soil-a review. J. Plant Nutr. Soil Sci. 166:145-167.

45. Walker, A. 1987. Further observation on the enhanced degradation of iprodione and vinclozolin in soil. Pestic. Sci. 21:219-231.

46. Warton, B., and Matthiessen, J. N. 2005. The crucial role of calcium interacting with soil $\mathrm{pH}$ in enhanced biodegradation of metam-sodium. Pest Manage. Sci. 61:856-862.

47. Weller, S. A., Elphinstone, J. G., Smith, N. C Boonham, N., and Stead, D. E. 2000. Detection of Ralstonia solanacearum strains with a quantitative, multiplex, real-time, fluorogenic PCR (TaqMan) assay. Appl. Environ. Microbiol. 66:2853-2858.

48. Zentmyer, G. A. 1955. A laboratory method for testing soil fungicides with Phytophthora cinnamomi as test organism. Phytopathology 45:398-404. 